\title{
To What Extent Could Shale Gas "Fracking” Contaminate Ground Water
}

\section{Al-Bajalan AR*}

Iraq-Erbil-Koya-Koya technical Institute, Iraq

\begin{abstract}
The possibility to economically produce gas from unconventional natural resources (shale gas) reservoirs has been made possible recently through horizontal well and hydraulic fracturing application. Hydraulic fracture or 'fracking 'is a technique that use in combination with horizontal drilling to stimulate or improve extracting natural gas from shale formation. However, this operation requires large volume of fluid to be pumped into the well at high pressure and flow rate in order to split the rock. This fluid is mainly water and mixed with sand and some chemical materials such as proppant. (Serve to prop open the fracture). Injection large volume of fluid into subsurface is not without risk. The recent report have highlighted the following issues: (earthquake induced by slip on nearby fault, emission of $\mathrm{CO}_{2}$ into atmosphere) However, this project focus on the effect of fracking operation on ground water and aquifer due to chemical additives and methane which is the main composition of shale gas. According to this report the gases and chemical additives may escape and flow into overlying ground water 'aquifer' in three possible pathways. Loss of wellbore integrity disposal of flow back water natural fracture network. This paper also looks at two case studies, North-East Pennsylvania, New York and Wyoming in the USA, which have the same geological shale formation. The study focuses on finding the potential impact of fracking technique that is used to extract natural shale gas on ground drinking water systems.
\end{abstract}

Keywords: Shale Gas; Fracking operation; Water contamination

\section{Nomenclature}

BTEX: Benzene, Tolyne, Ethylebenzene, Xylene

CBM: Coal Bed Methane

$\mathrm{CH}_{4}$ : Methane

$\mathrm{C}_{2} \mathrm{H}_{6}$ : Ethane

$\left(\mathrm{CH}_{2} \mathrm{CHO}\right)_{2}$ : Glutaraldehyde

EPA: Environmental Protection Agency

HF: Hydraulic Fracture

UNG: Unconventional Natural gas

$\mathrm{C}_{3} \mathrm{H}_{7} \mathrm{NO}$ : Di Methyl Formamide

$\mathrm{mg} / \mathrm{L}$ : Milligram per litter

\section{Introduction}

The fossil fuels consider as a main source of conventional natural energy, which provide world with energy [1]. However, growing energy consumption and depletion of accessible fossil fuels reserves increased demand of unconventional energy, such as shale gas. Producing natural gas from tight shale formation known as "Shale gas" is one of the most rapidly expanding trends in onshore and local natural gas exploration and production. This gas is trapped in impermeable rock formation, such as shale. It has fine grain rocks formation with low fluid permeability and this formation is commonly sedimentary rocks that are formed by deposits of mud, silt and some organic materials [2,3]. Shale formation contains high amounts of natural gas which is mostly methane and it is used to generate electricity and domestic heating. This formation need to be fractured in order to allow the natural gas to be passed through the porous of shale formation [4].

The process of extraction valuable natural gas from shale rocks is called hydraulic fracture (HF) or 'fracking. This technique was developed in 1949 by Halliburton oil service company to stimulate the of oil and gas production in conventional energy sources such as sandstone and limestone. However, advances in drilling and well stimulation technology have made this technique feasible to extract viable quantities of natural gas from unconventional resources, such as shale and coal bed methane formations (CBM) [5].

Fracking operation involves pumping high volume of pressurized water combine with sand into ground surface in order to create fissure in the rocks that contain natural gas [3]. This mixture keeps the created fracture rocks open. Then chemical materials such as biocide and acid will be added to expand through pre-existing fractures and force cracks to increase. When the cracks expand, natural gas will release and flow to surface [6].

According to Kinnaman [7], extraction natural gas from unconventional sources has positive impact on the global economy. However, there are highly concern about the potential impact of extensive extraction of shale gas by using hydraulic fracture technique on ground drinking water 'aquifer' due to the toxic and radiological chemical materials which are used by this technique. The main objective of this project is to provide a literature review on extraction natural gas from unconventional natural gas by using Hydraulic fracture and identifying the potential impact of shale gas fracking on ground drinking water systems [8,9].

${ }^{*}$ Corresponding author: Al-Bajalan AR, Iraq-Erbil-Koya-Koya technical Institute, Iraq, Tel: 009647505641986; E-mail: Ahmed_nafit@yahoo.com

Received June 22, 2015; Accepted July 08, 2015; Published July 18, 2015

Citation: Al-Bajalan AR (2015) To What Extent Could Shale Gas "Fracking" Contaminate Ground Water. J Pet Environ Biotechnol 6: 236. doi:10.4172/21577463.1000236

Copyright: (c) 2015 Al-Bajalan AR, et al. This is an open-access article distributed under the terms of the Creative Commons Attribution License, which permits unrestricted use, distribution, and reproduction in any medium, provided the original author and source are credited. 
Citation: Al-Bajalan AR (2015) To What Extent Could Shale Gas "Fracking" Contaminate Ground Water. J Pet Environ Biotechnol 6: 236. doi:10.4172/2157-7463.1000236

Page 2 of 7

\section{Unconventional natural gas (shale gas)}

Natural gas has been classified into two main types conventional and unconventional. The conventional gas is accumulated in sandstone and limestone formations and it is extracted by normal vertical drilling operation. However, the unconventional natural gas is difficult to be produced by using vertical drilling operation because it has trapped in very tight and low permeable reservoir formation such as shale [10].

Shale is a common type of sedimentary rock formed from deposits of mud, silt, clay and organic matter. Shale formation is very fine impermeable grained comprised of consolidated clay particles which were deposited in thinly laminated texture. Shale gas is considered as unconventional natural gas which is produced from shale formation and it is consider as dry gas and predominantly composed of methane (CH4). Unconventional natural gas or shale gas is located at depth between 1500 to 4000 meters. This gas is produced by using a new drilling technique which is known Hydraulic fracture or 'Fracking' [11] (Figure 1).

\section{Stages of shale gas production}

The process of unconventional gas well development for every individual well is as follows

Pre-production stage: This stage combines all the activities that the site required for shale gas production. This includes site preparation, drilling operation, hydraulic fracture and flow back waste and water treatment waste.

Production and processing: When drilling and hydraulic fracture activities completed, the second stage of shale gas extraction starts with installing well head production to collect the produced gas and transfer it to processing plant before distribution stage.

Transport and distribution: In this stage the produced gas will be distributed through pipeline. This stage is essentially has no different from the supply of conventional gas except the route from the well to the end customer might be different.

\section{Well plugging and abandonment}

When the wells are not able to produce gas anymore, or once the well reached to the end of its economic lifetime. The well should be properly decommissioned and plugged to protect the surrounding environment. This stage involves removal of equipment and infrastructure at the well

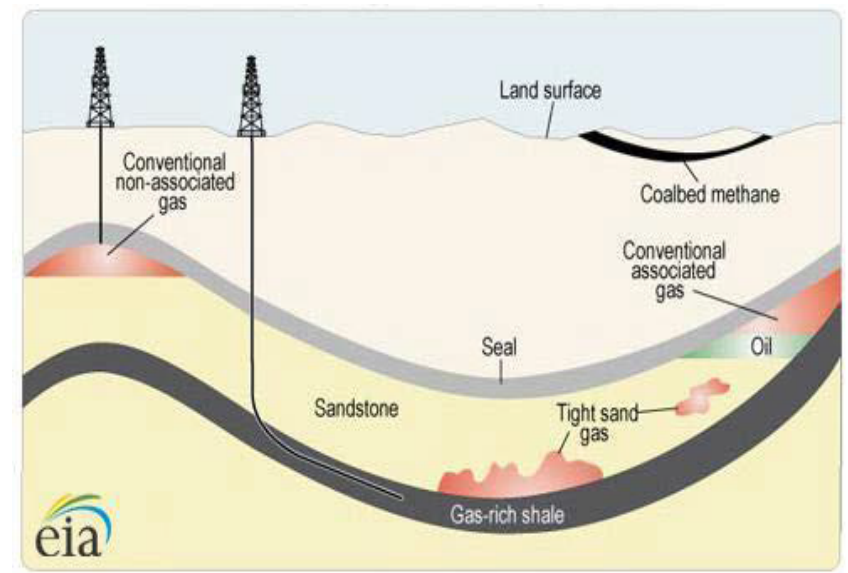

Figure 1: Types of natural Gas (EIA, 2010). site. Then the well is plugged with cement to ensure that the well is left in safe condition for future. The common process stage of shale gas extraction is shown in the diagram below.

In some fracture treatment more than one proppant are used to optimize the propping of fracture at different distance from the wellbore (Figures 2 and 3).

\section{Hydraulic fracture 'fracking' technique}

Hydraulic fracture or fracking refers to the process that is used in combination with horizontal drilling in order to produce natural gas from unconventional shale reservoir [12] (Figure 4). This process involves drilling vertical well above shale formation, then the drilling operation deviates horizontally (Figure 2). The flow diagram in the Figure 5 presents the common order stages that occur in HF treatment process. This process starts with transporting equipment onsite (field) when the equipment is rigged up. This involves making connection of all individual joints of equipment between frac head on the well, and frac pump. In addition, chemical additives equipment which launches

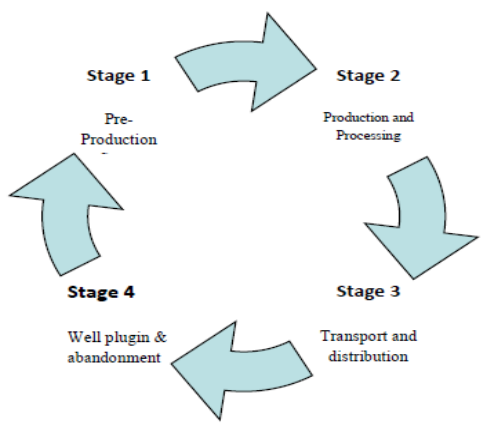

Figure 2: Well development process.

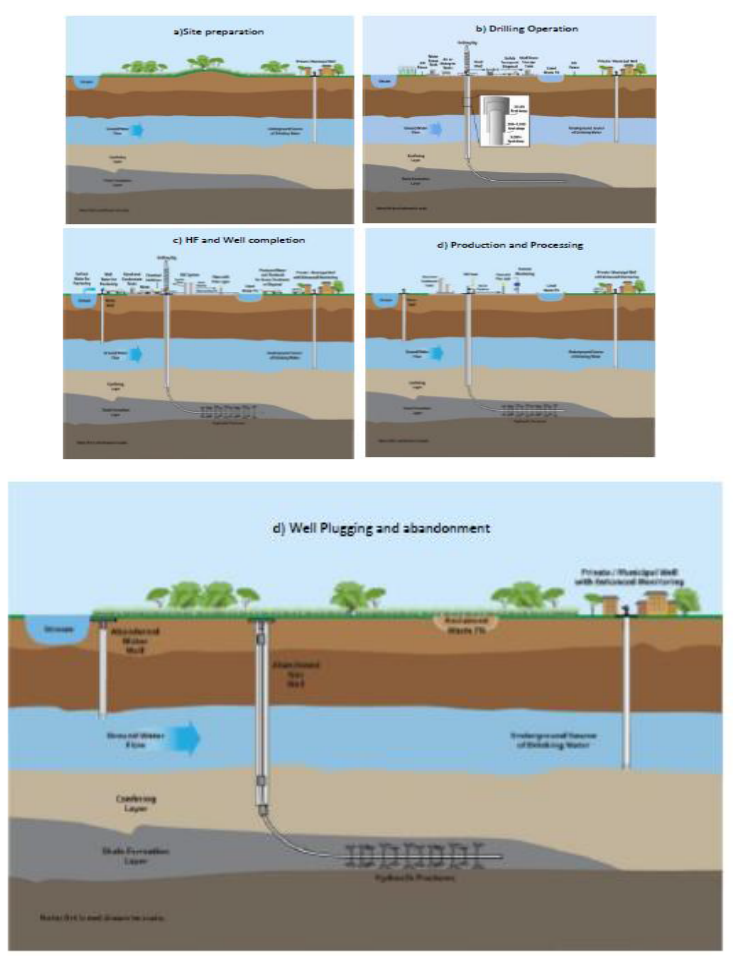

Figure 3: (a,b,c,d,e)Stages of shale gas production 


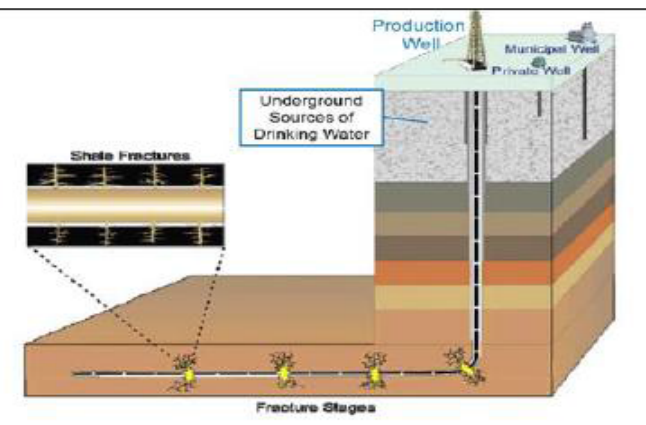

Figure 4: Schematic diagram showing HF technique.

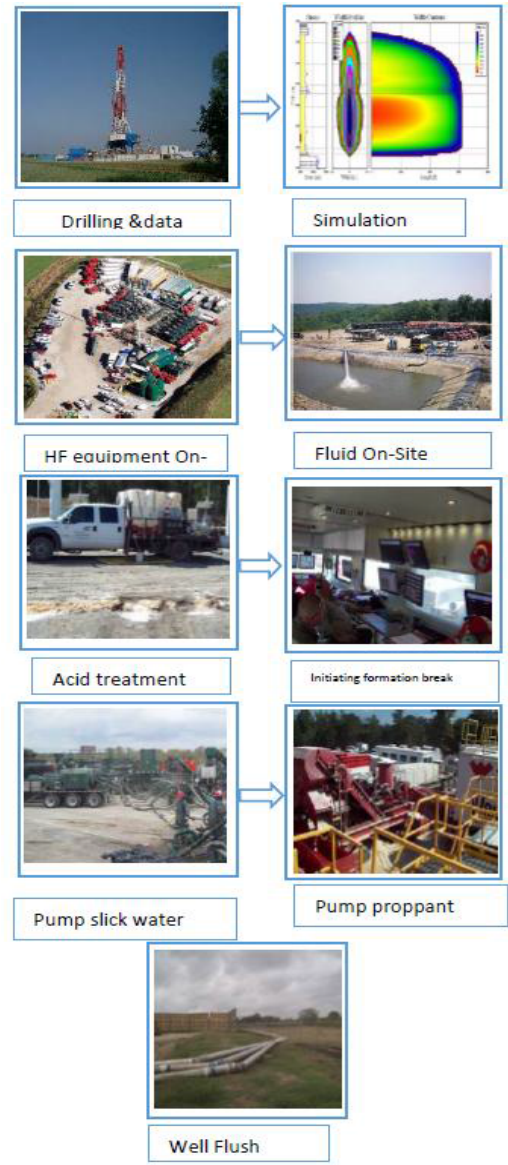

Figure 5: Flow diagram of a hydraulic fracture treatment process.

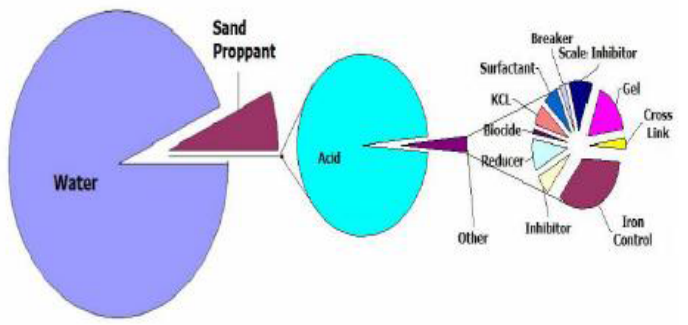

Figure 6: Composition of fracture fluid. fluids (water+sand) into fracking pumps. The fracture operation is accomplished after each stage of isolated interval (for example, $200 \mathrm{~m}$ ), then perforated by using preformation gun or tool. This perforations permit natural gas to move into wellbore through production phase of operation.

In order to isolate each fracture stage of a fracture treatment, a packer is used to isolate each fracturing interval. During drilling operations a highly pressurized fluids that is almost consisting of water, propping agent and chemical additives such as biocide, friction reducer and corrosion protections agent are injected down into the shale layers [13]. The injected water pressure should exceed the breakdown pressure of shale rocks in order to create fracture. However, the over high pressure induced the created fracture to extend beyond shale gas formation into water aquifer, allowing shale gas contaminates water layers [14]. As the fractures are created, the propping agent such as sand or ceramic beads are pumped into cracks to keep fracture open after reducing fracture pressure and allow natural gas to flow freely to the surface $[14,15]$.

\section{Fracking fluid and chemical additives}

According to Arthur et al. [16] and Environmental Protection Agency (EPA), water is the principal component of fracking fluid used in most shale gas formations. Ten thousand of barrel of water for every stage are required to stimulate fractures operators within shale formation.

However, various chemical constituents can be added to fracking fluid such as proppant in order to improve fluid performance [16]. This material is the second largest component of fracking fluid after water and it is granular material used to keep the created fracture open $[6,12]$. In addition to water and proppant, Hydrochloric acid (HCL) is utilized as essential additives to clean the cement that is accumulated in the casing and perforation stages. The figure below shows that water is an essential component (Figure 3) on ground drinking water 'aquifer'. The first is associated with rate of water consumption during this process where aquifer is the main source of water supply (Figure 6).

Second, the contamination of aquifer due to insufficient fracking well construction and design. The figure below shows the stages of fracking water cycles and the potential drink inking water issues associated each stage. According to Stuart [12], fracking fluid provides an ideal medium to growth bacteria because it contains organic gel. Therefore, Glutaraldehyde $\left(\mathrm{CH}_{2} \mathrm{CHO}\right)$ 2-biocide is used to prevent the well bore from bacterial attack. In addition, Corrosion inhibitor such as dimethyl formamide $\left(\mathrm{C}_{3} \mathrm{H}_{7} \mathrm{NO}\right)$ is also used to prevent corrosion in steel casing and well tubes. The concentration of these additives depends on temperature of down hole, casing and tubing types. The Table 1 illustrates typical constituents of Hydraulic fracture fluid and the main purpose of each one).

\section{Ground water concern associated with fracking}

Although shale gas is considered as clean gas energy because it has low carbon gas emission compare to conventional gases, the operations of extracting this gas have highly unavoidable environmental impact [17]. The British geological survey (BGS) (2011) has identified two potential impact of shale fracking process on ground drinking water 'aquifer'. The first is associated with rate of water consumption during this process where aquifer is the main source of water supply. Second, the contamination of aquifer due to insufficient fracking well construction and design. Figure 7 shows the stages of fracking water cycles and the potential drink inking water issues associated each stage. 


\begin{tabular}{|c|c|c|}
\hline Constitute & Purpose & Example \\
\hline \multirow[t]{2}{*}{ Salt } & Create a brine transmit & Potassium \\
\hline & fluid & Chloride (KCL) \\
\hline \multirow[t]{4}{*}{ Acid } & $\begin{array}{l}\text { Cleanup perforated } \\
\text { place of }\end{array}$ & Hydrochloric \\
\hline & & acid (HCL) \\
\hline & Cement and dissolve & \\
\hline & mineral & \\
\hline \multirow[t]{2}{*}{ Biocide } & prevent growing bacteria & Glutaraldehyde \\
\hline & which erode pipe & $\mathrm{CH}_{2}\left(\mathrm{CH}_{2} \mathrm{CHO}\right)_{2}$ \\
\hline Corrosion & Prevent corrosion of steel & n,n-dimethyl \\
\hline \multirow[t]{2}{*}{ Inhibitor } & pipe & formamide \\
\hline & & $\left(\mathrm{C}_{3} \mathrm{H}_{7} \mathrm{NO}\right)$ \\
\hline Friction & Reduce friction between & Polyacrylamide \\
\hline \multirow[t]{2}{*}{ reduction } & fracking fluids and well & $\left(\mathrm{C}_{3} \mathrm{H}_{5} \mathrm{NO}\right)$ \\
\hline & tubing & \\
\hline \multirow[t]{2}{*}{ Surfactant } & Increase fluid viscosity & Isopropanol \\
\hline & & $\left(\mathrm{C}_{3} \mathrm{H}_{8} \mathrm{O}\right)$ \\
\hline \multirow[t]{2}{*}{ Proppant } & Allow fracture to remain & Silica, quartz \\
\hline & $\begin{array}{l}\text { open so the gas can } \\
\text { scape }\end{array}$ & sand \\
\hline
\end{tabular}

Table 1: Hydraulic fracture fluid composition.

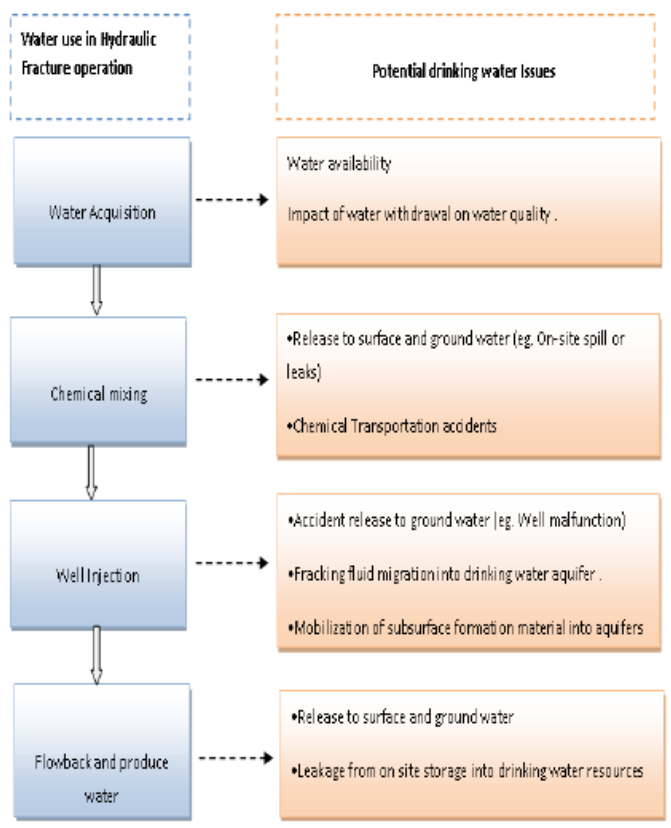

Figure 7: Water used in HF and its impact on ground water.

\section{Water scarcity}

Shale gas fracking is an activity, which requires extensive quantities of water to be injected underground in order to create fracture. The volume of water that is used in single horizontal fracking wells depends on the well drilling depth and geological formation characteristics. According to environmental protection agency [17] and United Nation Environment program UNEP [18] the required volume of water for single shale gas well is between nine to twenty-nine million liters.

For example, in 2011 the single fracking well in Pennsylvania and
New York has consumed more than nineteen million liter. In addition, Cuadrilla drilling gas company in the UK has used nearly to 8.4 million liters of water through extraction shale gas in Lancashire. The high volumes of water almost are provided by nearby surface or ground water resources and this will deplete the ground water resources. This depletion in ground water level has caused an increase in the dissolved salt in areas around fracking sites, growing bacteria, which effect on taste and odor of water [19-22].

\section{Water contamination}

One of the most highly debates on the ecological safety of shale gas extraction and hydraulic fracture technique is the potential contamination of drinking water. The potential risk comes from two sources injected fluid and released natural gas. According to Susan [12] fracking fluid, chemical additives and shale gas can escape and flow into overlying ground water 'aquifer' and contaminate it by three possible pathways :

\section{Well bore failure or loss of integrity}

Well integrity refers to preventing shale gas from leaking out the well by isolating it from other subsurface formation.

The successful of fracking operation depends on fluid design and mechanical integrity of wellbore that is determined by well casing design and construction. Well bore failure may arise from poor well integrity arising from:

- Blow out (uncontrolled escape of fluid from well to surface).

- Annular leak (weak communication which allows contaminates to move vertically either between casing or between casing and rock formation )

Arthur et al. [16] and Environmental protection agency find out that the chemical additives are used in fracking fluid such as Isopropanol, Methanol and BTEX (Benzene, Toluene, Ethylbenzene and Xyleneds) are toxic and radioactive materials. These chemical components can find a pathway to contaminate ground drinking water due to well bore failure (Figure 8).

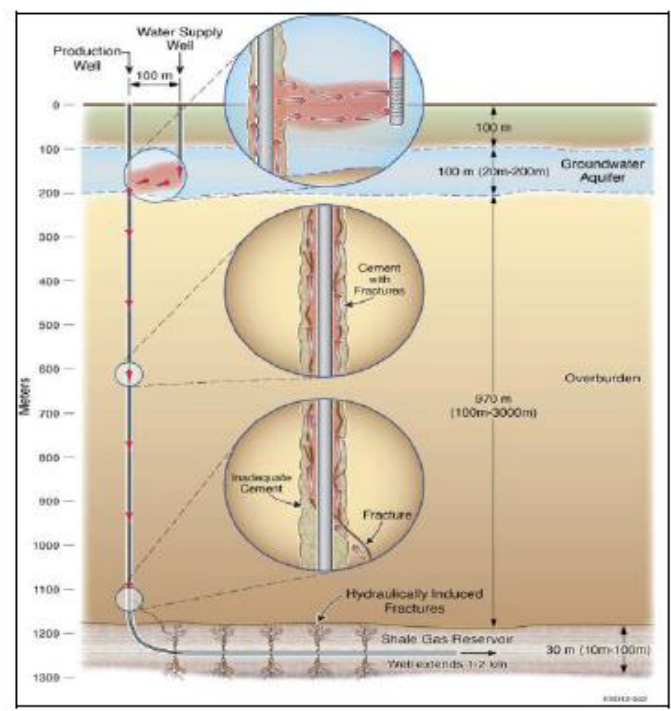

Figure 8: Well-bore failure. 


\section{Disposal of produced and flow back fluid}

The high salinity level (TDS up to $2500.000 \mathrm{mg} / \mathrm{L}$ ), toxic and radioactivity of produced and flow back of water from shale formation consider one of the main challenges that generated together with natural shale gas. When fracking operation is performed, a high proportion combination $(80 \%)$ of the injected fracking fluid and water return to surface through steel cased wellbore. The returner fluid is called 'flow back' and it contains highly contaminated, weakly radioactive materials with some toxic substances like benzene and methane [15]. The flow back fluid and produce water are temporarily stored on site in open evaporation pits or storage tanks in order to re injected into the fracking well [23]. However, there is a potential for leaks, release or spills associated with storage tank of flow back and produced water, which lead to contamination of shallow drinking water aquifer $[23,24]$.

\section{Natural fracture network}

Hydraulic fracture operation effect on the mobility of naturally occurring gases, such as Methane and Ethane in the shale formation and these gases may find pathway to contaminate ground drinking water.

As Vengosh et al. [9] points out that ground water may contaminate through fracking process itself rather than chemical additive and improper well casing and cementing design. The subsurface migration of Methane $\left(\mathrm{CH}_{4}\right)$ and Ethan $\left(\mathrm{C}_{2} \mathrm{H}_{6}\right)$ gases may happen due to induced existing fracture by hydraulic fracture technique (Figure 9).

\section{Methodology}

In order to perform this project, the concept of hydraulic fracture (HF) technique and main chemical compositions of fracking fluid have been reviewed in literature review. Then two case studies in North-East Pennsylvania and New York and Wyoming in the USA have examined to determine impact of fracking operation on ground drinking water. These two fields have the same geological context, which is shale formation, and both of them are gas fields. Data of shallow and deep ground water have been collected from these two case studies. Data of drinking water at different distances from active fracking well have also

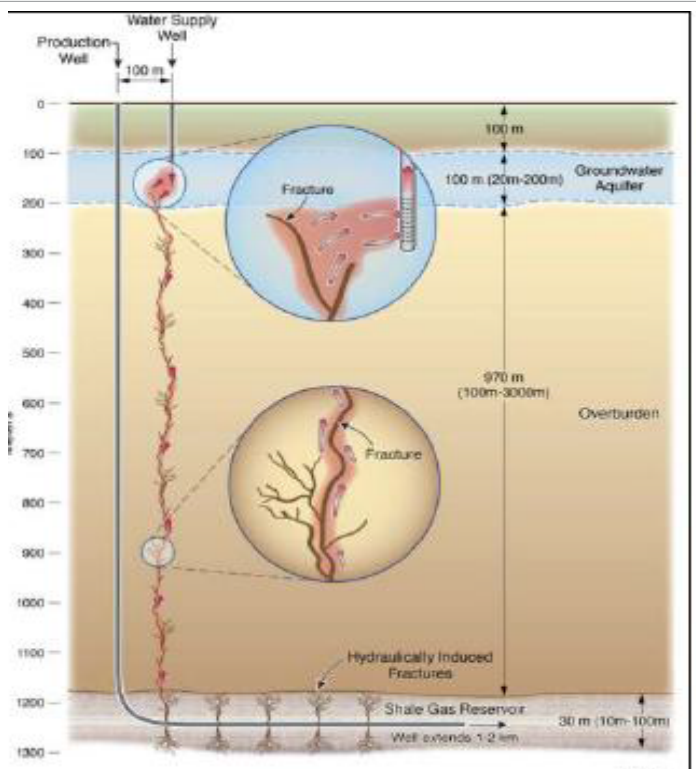

Figure 9: Natural fracture network. been collected. These two data are analyzed by measuring geochemical and isotopic features of ground water in order to identify concentration of dissolved methane gas, which is the main composition of shale gas in ground drinking water.

\section{Case \# 1}

Locations: North -East Pennsylvania and New York.

Geological formation: Catskill and Lockaven formation overlie on Marcellus shale reservoir in Pennsylvania, Genesee formation overlies on Utica shale reservoir in New York).

Field data: 68 ground drinking water samples at different depths.

\section{Case \#2}

Locations: Pavillion/Wyoming.

Geological formation: Lower Eocene Wind River Formation, underlying Paleocene Fort union formation, shale basin.

Field data: 53 samples of deep and shallow drinking water.

\section{Geochemical compound}

A considerable numbers of organic and inorganic geochemistry have been detected in shallow and deep ground drinking water due to fracking chemicals. For example, the high concentration of (BTEX) compounds in deep and shallow drinking water indicates that these compounds may be source of ground water contamination because these compounds are used in fracking fluid slurry and in a solvent. A high concentration of synthetic organic compounds, such as Isopropanol, Diethylene glycol and Ter-Butyl alcohol have been detected in ground water as shown in Figure 6 . Where most of these compounds are used as an agent in fracking fluid so that fracking operation may considers a source of contaminating ground drinking water. This report point out that Ter-butyl alcohol is a chemical component not expected to appear naturally in ground water.

\section{Results and Discussion}

\section{Methane concentration}

The result shows that the average contamination of methane gas which is the main component of shale gas in ground drinking water in the areas nearest to active gas extraction sites (fracking wells within $1 \mathrm{Km}$ ) higher than higher than neighboring non-extraction areas (no wells within $1 \mathrm{~km}$ ) as shown in Figure 6. There are three mechanisms explain the high rate of methane gas concentration near to fracking wells.

- Leakage of gas well tube casing due to vertical and lateral movement of methane through shale rock fracture.

- Spills of fracking fluid and chemical solid at surface as a result of tank rupture or equipment failure

- Physical displacement of shale gas or extension of fracture that already created by fracking technique could serve as conduits for ground water contamination (Figure 10).

\section{Geochemical compound}

A considerable numbers of organic and inorganic geochemistry have been detected in shallow and deep ground drinking water due to fracking chemicals. For example, the high concentration of (BTEX) compounds in deep and shallow drinking water indicates that these compounds may be source of ground water contamination because these 


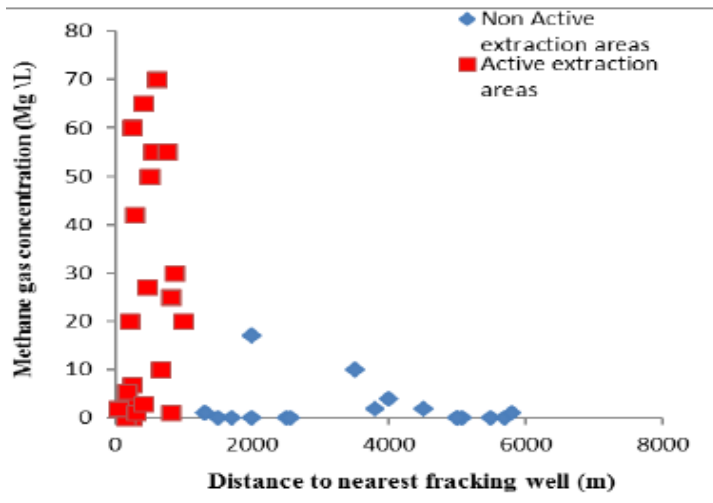

Figure 10: Methane concentration ( $\mathrm{mg} / \mathrm{l})$ according to active and non-active gas drilling well.

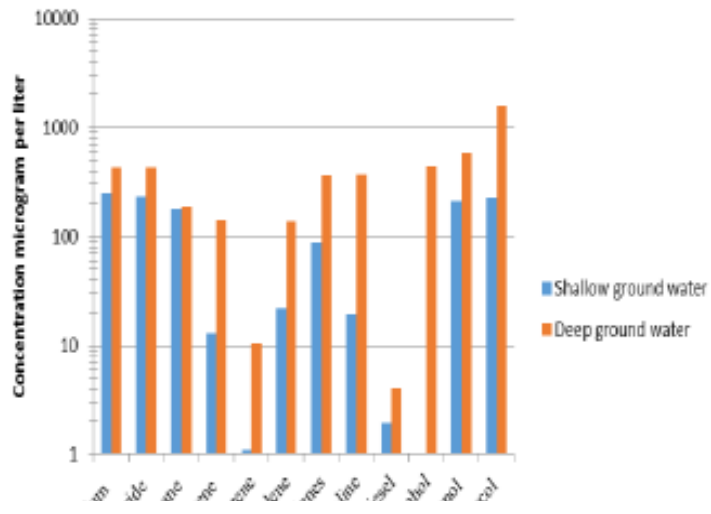

Figure 11: Organic and inorganic compound in deep and shallow water.

compounds are used in fracking fluid slurry and in a solvent. A high concentration of synthetic organic compounds, such as Isopropanol, Diethylene glycol and Ter-Butyl alcohol have been detected in ground water as shown in (Figure 6). Where most of these compounds are used as an agent in fracking fluid so that fracking operation may considers a source of contaminating ground drinking water. This report point out that ter-butyl alcohol is a chemical component not expected to appear naturally in ground water (Figure 11) [25].

\section{Conclusion}

Shale gas it considered as unconventional natural gas, which has low carbon dioxide emission, compare to conventional gas. However, the potential of ground water contamination is a key risk associated with process of extraction this gas. Most of the chemical additives that are used in hydraulic fracture fluid are toxic and radioactive materials and they may long term impact on natural ground water contamination.

- The results of analyzing data has identified that there are three significant potential pathways for contamination ground drinking water systems:

- Leakage of gas well casing because of vertical and lateral movement of methane through shale rock fracture.

- The fracking technique itself generates a new fracture or enlarge the existing fracture allowing methane gas migrate upward to ground water layers.

Spills of fracking fluid and chemical additives at surface as due to tank rupture or equipment failure
However, an additional analysis is required to determine the vertical and areal extend of shallow and ground drinking water contamination. Further investigation is also necessary to find most effective technology and regulatory solutions for developing shale fracking while protecting ground drinking water.

\section{Recommendation}

Further research is required for better geotechnical understanding of the fracture network produced by fracking operation particularly in more complex shale gas formation. In addition, research and should continuous into the feasibility of removing all toxic additives from fracking fluid.

\section{References}

1. EPA (2011) Draft Plan to Study the Potential Impacts of Hydraulic Fracturing on Drinking Water Resources. United States Environmental Protection Agency.

2. Dong Z, Holditch S, McVay D, Ayers WB (2012) Global Unconventional Gas Resources Assessment. Society of Petroleum Engineers, Calgary, Canada, pp. $1-13$.

3. Allen L, Cohen MJ, Abelson D, Miller B (2012) Fossil fuels and water quality The World's Water 7: 73-96.

4. Grealy N (2013) Fracking is one of the best things to happen to onshore gas exploration for a century. Engineering and Technology Magazine.

5. Wright BA, Pyke GW, McEnerney TJ, Getchell FJ (2011) Hydraulic Fracturing Issues and Research Needs for the Water Community. Water Research Foundation.

6. Howarth R, Ingraffea A (2011) Natural gas: Should Fracking Stop? Nature 447: 271-275.

7. Kinnaman TC (2011) The economic impact of shale gas extraction: A review of existing studies. Ecological economics and Environmental History 70: 12431249

8. Osborn SG, Warner NR, Jackson RB, Vengosh A (2011) Methane contamination of drinking water accompanying gas-well drilling and hydraulic fracturing Proceeding of the National Academy of the Sciences of USA 108: 8172-8176.

9. Vengosh A,Warner N, Jackson R, Darrah T (2013) The Effects of Shale Gas Exploration and Hydraulic Fracturing on the Quality of Water Resources in the United States. Procedia Earth and Planetary Science 7: 863-866.

10. Gregory BK, Vidic RD, Dzombak DA (2011) Water Management Challenges Associated with the Production of Shale Gas by Hydraulic Fracturing 7: 181-

11. Aguilera RF, Harding T, Krause F (2008) Natural Gas Production From Tight Gas Formations: A Global Perspective. 19th World Petroleum Congress, Madrid, Spain.

12. Stuart ME (2012) Potential groundwater impact from exploitation of shale gas in the UK. British Geological Survey, NERC Open Research Archive.

13. Forster D, Perks J (2012) Climate impact of potential shale gas production in the EU. AEA Technology.

14. Zoback M, Kitaseri S, Copithorne B (2010) Addressing the Environmental Risks from Shale Gas Development. World Watch Institute, pp. 1-19.

15. EPA (2004) Evaluation of impacts to Underground Sources of Drinking Water by Hydraulic Fracturing of Coalbed Methane Reservoirs Study (2004) United States Environmental Protection Agency.

16. Arthur DJ, Bohm B, Coughlin J, Layne M (2009) Evaluating the Environmenta Implications of Hydraulic Fracturing in Shale Gas Reservoirs. SPE Americas E\&P Environmental and Safety Conference. San Antonio, Texas, pp. 1-22.

17. DiGiulio DC, Miller C, Wilkin RT (2011) Investigation of Ground Water Contamination near Pavilion, Wyoming. Office of Research and Development National Risk Management Research Laboratory, pp. 5-42.

18. UNEP (2013) Can we safely squeeze the rock? Environmental development 6: 86-99.

19. Andrews J (2013) The Carboniferous Bowland shale gas study: Geology and Resource Estimation. London, BGS.

20. Susan W (2012) Discovering shale Gas: An Investor Guide to Hydraulic Fracture: IRRC Institute. 
Citation: Al-Bajalan AR (2015) To What Extent Could Shale Gas "Fracking" Contaminate Ground Water. J Pet Environ Biotechnol 6: 236. doi:10.4172/2157-7463.1000236

Page 7 of 7

21. Slatt RM (2011) Important geological properties of unconventional resource shales. Central European Journal of Geosciences 3: 435-448.

22. IEA (2012) World Energy Outlook 2012 - Special Report - Golden rules of a golden age of gas.
23. Odera A, Burley S, Lewis A, Hardman M, Haynes P (2005) The world according to gas Petroleum geology conference series 6: 571-576.

24. Rahm D (2011) Regulating hydraulic fracturing in shale gas plays: The case of Texas. Energy Policy 39: 2974-2981.

25. Roelofs A, Headen C, Tailant J (2012) Hydraulic Fracturing. Centre for Human Rights and Environment (cedha). 